\title{
High Impact Entrepreneurs: Do not Measure the Size but the Influence
}

\author{
I.S. Darmo * \\ Institut Teknologi dan Bisnis Kalbis \\ Jakarta, Indonesia \\ * ika.darmo@kalbis.ac.id \\ H. Mulyadi * \\ Universitas Pendidikan Indonesia \\ Bandung, Indonesia
}

\begin{abstract}
Industrial revolution 4.0 gives an extraordinary impact on the rise of widespread digitalization of influence in modern entrepreneurship. This study held to find out the magnitude of business impact analyze (BIA) of the innovation and the new business model and initiated by business startup; especially the influence of the business new values to the community. This qualitative research relies on data validity of literature studies which supported by depth-interview activities to 5 start-up entrepreneurs in the creative industry in East Jakarta, Indonesia. The results of this study indicate that most of success of entrepreneurial startup is not determined by firm or firm size, but is determined by how their business impact analysis (BIA) and innovation business models much influence the startup generates for the society's welfare.
\end{abstract}

Keywords-Business Impact Analyze; Innovation; Startup; Community

\section{INTRODUCTION}

Revolution 4.0 phenomena

Development of technology and information on the culture of modern society has brought things that were originally in the imaginative realm of science fiction into the fact of everyday life. Industrial Revolution 4.0 becomes a great leap that has transformed many human lives. Activities originally carried out in bulk with the help of mechanical robots coordinated with computer technology, nowadays everything has been systematically synchronized to serve and fulfill human needs.

The term Industrial Revolution 4.0 itself was officially born in Germany precisely when it was held [1]. The German state has a great interest in this regard because Industry 4.0 is part of its development plan policy called High-Tech Strategy 2020. [2] explained that the policy aims to keep Germany always at the forefront of manufacturing. In line with this opinion, [3] described that internet massive operation, sensors and embedded systems, completely new opportunities are opening up for new combinations of mental, physical and mechanical work.

Industry 4.0 is predicted to have great potential benefits. Most opinions on the potential benefits of Industry 4.0 are improvements in speed, production flexibility, improved service to customers and increased revenue [4]. The realization of the potential benefits will have a positive impact on the economy of a country [5].

[6] explains the industrial revolution 4.0 has fundamentally changed human life and work. Unlike the previous industrial revolution, this fourth-generation industrial revolution has a wider scale, scope, and complexity. The advancement of new technologies that integrate the physical, digital and biological world has affected all disciplines, economics, industry, and government. Areas that experience breakthrough thanks to new technological advances include artificial intelligence robotics, nanotechnology, biotechnology, quantum computer technology, block-chain (such as bitcoin), internet-based technologies, and 3D printers.

Some other countries also participate in realizing the concept of Industry 4.0 but use different terms such as Smart Factories, Industrial Internet of Things, Smart Industry, or Advanced Manufacturing [7]. Despite the mention of different terms, they all share the same goal of increasing the competitiveness of each country's industry in the face of a highly dynamic global market. The condition is caused by the rapid development of the utilization of digital technology in various fields [8].

Industrial revolution 4.0 in Indonesia

The Industrial Revolution 4.0 enlarges enormously massively in the fields of Business and Entrepreneurship around the world [9], as well as in Indonesia industrial fields [10]. Especially since President Joko Widodo inaugurated a roadmap or roadmap called Making Indonesia 4.0. The President hopes, the Industry 4.0 sector could contribute to more job creation as well as new technology-based investments. The implementation of the fourth generation industry must be followed by the establishment of a healthy and sustainable ecosystem to be effective and able to mobilize all sectors of the economy [11]. 
Center (BCIC) or TohpaTI Center, Incubator Business Center in Semarang, Makassar Technopark, and Mobile Design Center in Batam [11].

In the future, innovative areas become the basis of innovation and creativity for industry players in the digital field who want to develop software, website, application, film and animation, and other digital programs [15]. This is in line with the government's target of projected Indonesia to become Southeast Asia's largest digital economy by 2020 by targeting 1,000 technopreneurs, valuing businesses of up to 100 billion dollars. In addition, it is also preparing a roadmap or roadmap on Indonesia's strategy to implement a new industrial era or industrial technology 4.0. The technology includes artificial intelligence, internet of things, big data, robotics and 3D printing. There are five lighthouse industries that we prepare, namely the food and beverage industry, textile and apparel, automotive, electronics, and chemicals [16].

Previous Research, the relationship between company size and performance is a classic problem that has long been discussed in various forums. [17] study illustrates that the rate of growth of the firm does not depend on its size. This finding is then referred to as the "Proportional Securities Law"; where there is a theory that the growth of a company is not related at all to the size of the company. Therefore, large and small companies have the same probability of achieving a certain growth rate in a given period. Furthermore, some studies support the Law of Gibrat and many other refusals. Some studies conclude that there is a dependent relationship between firm size and performance, which can be a negative and positive impact [18].

Contrary to previous opinion, [19] shows a positive relationship between firm size and profitability, and [20] describes equally that the larger the company, the higher the rate of profit. Meanwhile, in other studies more emphasize the conclusion of growth in the review based on data or annual report owned by the company.

\section{METHOD}

This research uses qualitative research method with the instrument of depth interview to the informant who becomes respondent in this research.

The study involves 5 start-up entrepreneurs in East Jakarta. This study was conducted in the period April to May 2018.

The researcher records each answer to the questions submitted by the respondent and develops follow-up questions from each answer submitted by the respondent until the final conclusion of the variable becomes the object of observation (snowball interview methods).

\section{RESUlTS AND ANALYSIS}

Based on the questions asked of the respondents, the following conclusions are obtained:

Startup entrepreneurs have great confidence in the many business opportunities that can be utilized in the era of Industrial Revolution 4.0 in Indonesia. construction of incubation buildings for startup businesses, among others in Bandung Techno Park, Bali Creative Industry 
[3] Bloem, J., Van Doorn, M., Duivestein, S., Excoffier, D., Maas, R. \& Van Ommeren, E. 2014. The Fourth Industrial Revolution. Things Tighten.

[4] Crnjac, M., Veža, I. \& Banduka, N. 2017. From Concept to the Introduction of Industry 4.0. International Journal of Idustrial Engineering and Management, 8(1): 21-30.

[5] Lavanya, B., Shylaja, B.S. \& Santos, M.S. 2017. Industry 4.0 - The Fourth Industrial Revolution. International Journal of Science, Engineering, and Technology Research (IJSETR), 6(6): 1004-1006.

[6] Schwab, K. 2017. The fourth industrial revolution. United States: Crown Business Press.

[7] Okano, M.C. 2017. IOT and Industry 4.0: The Industrial New Revolution. International Conference on Management and Information Systems 25: 26.

[8] Roblek, V., Meško, M. \& Krapež, A. 2016. A complex view of industry 4.0. Sage Open, 6(2): 2158244016653987.

[9] Morrar, R., Arman, H. \& Mousa, S. 2017. The Fourth Industrial Revolution (Industry 4.0): A Social Innovation Perspective. Technology Innovation Management Review, 7(11): 12-20

[10] Naude, W. 2013. Why Indonesia Needs a More Innovative Industrial Policy. ASEAN Journal of Economics, Management, and Accounting, 1(1): 48-65

[11] Ministry of Industry. 2018. Indonesia's Fourth Industrial Revolution Making Indonesia 4.0. Kementerian Perindustrian Republik Indonesia.

The conclusions that can be reported in this study are: startup entrepreneurs become the choice of profession that should be considered for the young generation of Indonesia. Courage and carefulness in exploiting change opportunities determine the success of an entrepreneur startup in developing its business. Business size is no longer a reference to business success, startup entrepreneurs rely on applications and digital management systems to manage and grow their companies. Business Impact Analysis (BIA) becomes one of the main sources of the strategy implemented in startup companies. The greater impact is given by startup companies to the public, the higher the value of the company in the eyes of the public; not from a physical point of view but rather to the digital form used by the everyday society. This proves that the emergence of entrepreneur startup become one of the change agents that push Indonesia to be more competitive in facing business competition at international level. New startup companies have a tremendous opportunity to 'go public' by expanding their services to a vast region with no state restrictions. The greater the number of people who use the products or services offered by the startup company, the greater the impact generated by the startup to the community

\section{REFERENCES}

[1] Kagermann, H. Lukas, W.D. \& Wahlster, W. 2013. Final report: Recommendations for implementing the strategic initiative Industrie 4.0. Industrie 4.0 Working Group.

[2] Heng, S. 2014. Industry 4.0: Upgrading of Germany's Indus-trial Capabilities on the Horizon. Deutsche Bank Research.
[12] Widjaja, N. 2017. Opinion: Indonesia Needs More Scale-Ups, Not More Startups. [Online]. Retrieved: https://www.forbes.com/sites/outofasia/2017/12/11/opinion-indonesianeeds-more-scale-ups-not-more-startups/. Accessed 27 March 2018

[13] Kasali, R. 2017. Meluruskan Pemahaman soal Disruption. [Online]. Retrieved:

https://ekonomi.kompas.com/read/2017/05/05/073000626/meluruskan.p emahaman.soaldisruption. Accessed 27 March 2018

[14] Aida, I. \& Hati, S.R.H. 2013. Social Entrepreneurship in Indonesia: Lessons from the Past. Journal of Social Entrepreneurship, 4(3): 277 301 .

[15] Devezas, T.C., Leitao, J., Sarygulov, A. 2016. Industri 4.0 Entrepreneurship and Structural Change in The New Digital Landscape. Heidelberg: Springer.

[16] Suradi, S., Yasin, R.M. \& Rasul, M.S. 2017. Increasing technopreneurs for a developing a nation: The majlis amanah rakyat (MARA) experience. Journal of Technical Education and Training, 9(1)

[17] Bhattacharyya, S. \& Saxena, A. 2009. Does the firm size matter? An empirical enquiry into the performance of Indian manufacturing firms. SSRN Electronic Journal.

[18] Prasetyantoko, A. \& Parmono, R. 2012. Does firm size matter? An empirical study of firm performance in Indonesia. International Research Journal of Business Studies, 2(2): 87-97.

[19] Punnose EM (2008). A profitability analysis of businessgroup firms versus individual firms in the Indian electrical machine manufacturing industry. The Icfai J. Manage. Res., 7: 52-76

[20] Shepherd, W.G. 1986. On the core concept of industrial economics, in de Jong H.W. and Shepherd W.G. Mainstreams in Industrial Organisation, Dordrecht: Martinus Nijhoff 